\title{
"Race" and the upsurge of antagonistic popular movements in Sweden
}

\section{Carl-Ulrik Schierup, Aleksandra Ålund \& Anders Neergaard}

To cite this article: Carl-Ulrik Schierup, Aleksandra Ålund \& Anders Neergaard (2017): "Race" and the upsurge of antagonistic popular movements in Sweden, Ethnic and Racial Studies, DOI: 10.1080/01419870.2017.1361541

To link to this article: http://dx.doi.org/10.1080/01419870.2017.1361541
(C) 2017 The Author(s). Published by Informa UK Limited, trading as Taylor \& Francis Group

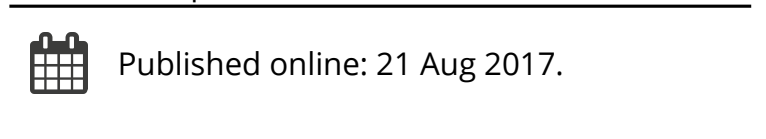

Submit your article to this journal $\pi$

\section{Џ Article views: 95}

Q View related articles $\triangle$

View Crossmark data $\asymp$ 


\title{
"Race" and the upsurge of antagonistic popular movements in Sweden
}

\author{
Carl-Ulrik Schierup, Aleksandra Ålund and Anders Neergaard \\ REMESO, Linköping University, Norrköping, Sweden
}

\begin{abstract}
Across a crisis-stricken Europe battles rage for post-neoliberal hegemony, with "race" and "austerity" as central signifiers. One of the places where the frontlines are most pregnant is Sweden; long perceived as a role model for its welfare state, cultural equity and social equality. Sweden is, however, facing social conflicts following in the tracks of a deep transformation in terms of welfare cuts, racialization and growing social polarization, targeting in particular a disadvantaged migrant and post-migrant population. On that background, the paper focuses on the upsurge of mutually antagonistic popular movements - "racist" and "anti-racist". We use Sweden as an exemplary case of Europe's present Polanyian moment, reminiscent of the 1930s. Yet, current upheavals expound, the authors claim, a different configuration of crisis and racism as well as a dissimilar utopia for the imagineering of nation and community.
\end{abstract}

ARTICLE HISTORY Received 6 November 2016; Accepted 12 July 2017

KEYWORDS Racism; social movements; migration; sociology; social class; Sweden

\section{Introduction}

By the second decade of the twenty-first century, at a moment marked by the reality of extensive immigration and a multiethnic social reality, speech on good governance in the EU has become dominated by the hailing of imagined mono-cultural nations. This is a common-sense racializing discourse, which has for decades been present as an influential political stratagem in European politics. But it has come to dominate a wide realm of public-political debate across the European Union, especially after the 2008 financial crash underscored a search for legitimacy for austerity politics through a discourse blaming "immigration", cultural pluralism and the racialized subaltern Other for the decline of citizenship, welfare and social cohesion.

This new-old racializing nativism is a toxic terrain which the political mainstream increasingly shares with extreme-right anti-immigration movements 
and parties across Europe. These appear, on their part - in spite of their philosophical roots and present-day political agendas bordering on fascism increasingly successful in cleansing their public-political stigma of "racism". By successfully positioning itself neither to the right, nor to the left, but as both right and left (e.g. Holmes 2000), and foremost the "true" representation of the nation, this contemporary populism potentially appeals to broad categories of European populations, suffering economic insecurity, social crisis and identity loss. It can appeal to parts of a traditionally conservative and nationalist right, frustrated by perceived threats to national self-esteem represented by globalization, Europeanization and transnational migration. But explaining all ills through migration and alien cultures also vies for the allegiance of parts of the traditional left, frustrated with the denigration of the welfare state and the precarization of work. In the process, "Culture" has systematically been fabricated into what Ernesto Laclau (2005) calls "a floating signifier" with a plastic capacity of gluing together the multitude of disparate and often contradictory political claims embraced by a multifaceted contemporary European racism. Such a deployment of "culture" is not confined to the extreme right, but is a shared heritage and contemporary reality of Western democracy. Albeit clad in the unsullied robe of "culture", "the problem of the color line", which Du Bois $(1903,13)$ once called "the problem of the Twentieth Century", persists at the threshold to the twenty-first. Its differentiating signifiers of "color, bone and hair" now figure as (mostly) invisible, but no less important, subscripts. They continue to direct the bio-political management of imagined racial difference through the politics of outer and inner border control and securitization, policies of counterinsurgency, of urban segregation, and of discriminatory social and labour market policies.

This is the general context in which an ominous transformation of our present has unfolded, also in Sweden for long famed for its exemplary social model, regarded as merging extended rights of citizenship with a politics freed from nativist obsession. In the booming reformist spirit of the mid1970s, new policies had been conceived in terms of "Equality, Partnership and Freedom of Choice", confidently rephrasing the revolutionary 1789 trinity into a credo of an inclusive welfare society: a particular Swedish "exceptionalism" (Schierup and Ålund 2011). It was specifically designed to offer a ramified body of substantial rights of citizenship for all - civil, political, cultural, social and labour rights - independently of ethnic identity or national origin. It included fast access to full formal citizenship for newcomers and inaugurated a solidaristic policy of asylum and refugee reception. It was supposed to guarantee empowerment to migrants and ethnic minorities of migrant background through principled and actual access to democratic participation on the basis of their unique historical experience and cultural identity. While there has always been a remarkable gap between professed ideals and another reality, from the spring of 2016 , this former showpiece of socio- 
cultural inclusionism and public welfare had come to stand virtually inflamed by a cynical right-left game of thrones. It threatens to pragmatically dispose of what still remains of a model Swedish exceptionalism's moral political foundations in the dustbin of history (Ålund, Schierup, and Neergaard 2017).

Sweden is still a country with a privileged position in the international division of labour. It is a country for which a continued open migration and asylum policy would combine allegiance to humanitarian ideals with forward-looking opportunities for filling gaps in the labour market, for boosting economic dynamism, for redressing a crisis in an undermanned welfare institutional system and for successfully combating a looming demographic crisis; yet despoiled through the breakdown of the broader solidarities needed for pursuing long-term goals of sustainable economic development and a resuscitated social welfare (Schierup and Scarpa 2017). But a looming dismantling of the country's welfare system can now be conveniently hidden behind a smokescreen of "the refugees". Thus, the "refugee" or "migration crisis" is the symptom of a deeper structurally and institutionally grounded crisis of solidarity. It is about a trajectory driven by neoliberal austerity politics, which, since the mid-1990s, has made Sweden the OECD member with the fastest growth of social inequality. A deepening inequality has been produced through the politics of deregulation, privatization and changes in the taxation regime favouring the well off and skinning the already disadvantaged on the margins of the social welfare system - a dismantling of the social fabric. It has produced precarization of work, citizenship and livelihoods (Schierup and Scarpa 2017). Taken together, all of this is generating an existential insecurity and a crisis of the polity and of identity. It is a state which has - using a concept coined by the historian Karl Polanyi ([1944] 2001) in his analysis of the economic and political crisis of the 1930s - been driven by a destructive "commodification" of labour, money, and urban and rural environments. In The Great Transformation, he suggests that this will, in turn, breed a contentious countermovement aiming to "re-imbed" the unregulated market in protective social institutions.

This is not the place to review a huge contemporary academic debate on the work of Polanyi, its insights, weaknesses and flaws. Suffice here to emphasize, with Michael Piore (2008), that although the theories that have guided deregulation and globalization today are the "direct descendants of the laissez faire ideas that guided globalization a century ago", the kind of state-driven social policies that emerged from the Great Depression of the 1930s have largely been discredited. Given the erosion of citizenship and a waning faculty of the nation state to uphold protective social institutions, in the era of globalization, the Polanyian problematic of "society" versus the "market" needs to be critically revised to meet the challenges posed by a new matrix of social development. Nancy Fraser (2013) for one emphasizes the centrality of Polanyi's analysis, but argues that it is neither analytically 
nor normatively sufficient to focus on this "double movement" of social protection versus commodification. She points in her reception of The Great Transformation to a distinction between an "oppressive protection", embodied in étatist social policies versus an "emancipation from domination" represented by claims and practices of an array of "new social movements"; a "triple movement", in addition to market-driven "commodification" and "social protection" embodied in state institutions. Notwithstanding their often ambivalent relation to both market and state, new social movements represent struggles for emancipation, Frazer claims, aiming at unmasking power asymmetries and exposing contradictions resting in state-driven social protection and the oppressive effects of uncontrolled markets.

Seeing marketization, social protection and emancipation as three movements, we argue, facilitates an analysis of today's contestations of political hegemony in Sweden. From this perspective, we interrogate in the following pages a Swedish scenario that intimates driving forces of social movements of today - albeit subject to different global and local conditions - similar to those of a composite global countermovement against a disruptive rule of financial capitalism and an unbridled market economy that swept across the world of the 1930s. As in the 1930s - with Stalinism, Fascism and Social Democracy today's countermovement embraces a diversity of actors and possibilities.

Using the case of Sweden and focusing on the upsurge of mutually antagonistic popular movements - "racist" and "anti-racist" - this article discusses a situation in which a neoliberal development, marking Sweden since the beginning of the 1990s, is becoming challenged by counterhegemonic movements. While exposing different visions of the future, we see these movements as counterpoised hallmarks of the contemporary crossroad for the development of Swedish society. We analyse, in the first part of the paper, the shifting racial discourse of the extreme-right radical party, the Sweden Democrats and the articulation of the party's advance with the current political conjuncture in Sweden. In the second part of the article, we examine a politically articulate new urban justice movement carried forth by young Swedes from migrant backgrounds. We ask whether this movement of "the Rest" within "the West" ${ }^{11}$ may harbinger a brighter future that merges the heritage of a seemingly exhausted social democratic project with the incipient movement of young Swedes in ways that could transgress the oppressive racializing dynamics that was always present in the "Swedish Model", but which has been exacerbated with the surge of the extreme right today?

\section{Countermovement or cow deal? A brown-blue alliance in the making}

Today, in many states of Europe as in the European Parliament, extreme right, racist and fascist parties have grown. While gaining support for a number of reasons, as anti-globalist and flag-bearers for a growing distrust of the political 
system, the central interpellation of the Extreme Right Parties (Fennema 1997) operates through the construction of racialized or ethnicized "Others" - the Muslim, the Roma, the black or the "Migrant" in general - threatening the nation and the people.

In a critique of much of the established research, Mudde (2010) stresses the close relationship between the populist radical right and mainstream Western political democracy, arguing that "the key difference is not to be defined in kind, i.e. by fundamental opposition (i.e. antithesis), but in degree, i.e. by moderate versus radical versions of roughly the same views. Moreover, the typical right populist attitudes and ideas are not marginal under normal conditions; they are fairly widespread, if often in a more moderate form than expressed by the populist radical right parties" (Mudde 2010, 1178). While Mudde eschews naming these parties racist, he uses empirical data demonstrating that racism is alive and pungently present in Europe.

Expanding Mudde's analysis, we argue that racisms are intrinsically part of the social formation of European states. In understanding the manifestation of racisms, Stuart Hall's (1997) approach to race as a floating signifier provide tools for a further analysis. In a Swedish context, in which the concept of "race" has generally been abolished in usage following the Second World War (Holocaust) and the 1960s (decolonization and the U.S. civil rights movement), race has lingered on in unspoken forms, that every now and then have resurfaced in public discourse. A major mode in which race has been expressed in what we would call the mainstream politics is a racialization of refugees and immigrants related to the contemporary neoliberal project of commodification based on an exploitative racism. It points back to both the legacy and the covert forms of the geopolitics of racism represented by colonialism, imperialism and neo-colonialism (Mulinari and Neergaard 2017; cf. Fennema's discussion of colonial racism 2005).

Through migration, Sweden, like most other European states, has become increasingly diverse in terms of the national origin of its population, ethnic identity and religious affiliation. With reference to the "peril of migration", the imaginary threat of cultural diversity to social solidarity and cohesion of the nation state has, in turn, become a lynchpin for contemporary parties spanning what Fennema (1997) differentiate as protest, racist and extremeright positions and propelling racializing politics across the continent. One example is the rapid upsurge of the Sweden Democrats (Mulinari and Neergaard 2017).

Sweden for long did not harbour any successful Extreme Right Party, barring the short-lived rise and fall of the party, New Democracy 1991-94 (Rydgren 2002) accompanied by street-level neo-Nazi and overtly racist movements (Pred 2000). In 2010 the Sweden Democrats entered parliament with the support of close to 6 per cent, and in the general election of 2014 the party more than doubled its support (13 per cent). If a general election 
were to be held as this is written, the Sweden Democrats would, according to the polls, be the second largest part in parliament. It is a party that grew from remnants of old Nazi alignments, racist and neo-Nazi organizations (Block 2001). The parliamentary breakthrough in 2010 was propped up by an interpellation mainly revolving around a perceived "Muslim threat" to Sweden's national cultural and social fabric (Hellström 2016). It was driven by major media breakthroughs, representing cultural incompatibility in line with what Fennema designates as racism through quasi-biological attributes $(2005,9)$. One was an op-ed piece published in the leading daily tabloid newspaper framing Muslims and Islam as the most serious threat to Sweden since the Second World War. Another was a propaganda film aired on national TV and uploaded on YouTube. ${ }^{2}$ It pitted an elderly white "Swedish" woman against "Muslim" women wearing Burkas and surrounded by many children. It projected an image of how decreasing welfare for elderly "Swedes" was a direct effect of immigration by culturally incompatible "Muslims" portrayed in quasi-biological attributes.

Despite the cloaked albeit prevalent racism of Sweden Democrats representatives, popular support is increasing for the Sweden Democrats. With the party's strategic position in parliament, it has become able to destabilize Swedish politics. It purports a political project that in some aspects questions globalization and neoliberalism. It may be about nostalgia for an idealized (ethnically or racially "pure") Swedish "People's Home"; a national welfare state that once was, or more correctly, imagined (Norocel 2016). The migrants are seen as pollution and the destruction of what is truly Swedish, while the established left, imagined as ranging from socialists and social democrats to feminists and anti-racists, are seen as betraying Sweden and the ideals of the nation and the family. Thus, the destruction of the nation through immigration and the import of foreign cultures with a particular focus on Islam are at the core of the party's political imagination. The Janus-faced combination of being both racist against migrants, framing race through culture and otherness, and at the same time, a self-presentation as being anti-racist through expelling some members resorting to a discourse of biological racism and/ or violence is we contend a successful strategy based on skilfully juggling race as a floating signifier.

The question remains, however: why now and why with such rapidly growing success?

We contend that the rise of Sweden Democrats is only partially based on fruitful efforts to distance the party from the crude and overt racism of its own past, flagging overt biological signifiers of "race", and replacing them with a more covert racism communicated through subtler metaphors of "culture". Parallel to this strategy of cleansing its official image, which it shares with other extreme-right parties in Europe, representatives and individual members of the Sweden Democrats continue to disseminate a more 
traditional overt and crude racism, especially through social media. An example is a Sweden Democrats municipal representative and lay judge asking on Facebook "Can someone place themselves on the Öresund bridge with a machine gun" in a situation where thousands of refugees were entering Sweden through the bridge applying for asylum. ${ }^{3}$ While a more overtly aggressive racism is mostly directed against Muslims or migrants in general, at times it does also entail anti-Semitism as in the case of a member of Parliament using the classic idea of Jews controlling media, or another laughingly recounting a story in which Nazi work colleagues are kicking lambs at a slaughter house pretending that they are Jews. ${ }^{4}$ This, apparently, is not affecting the party's standing in opinion polls negatively. Despite this, or perhaps more accurately through the combination of a Janus-faced approach - explaining that everything that has gone wrong is caused by migration and migrants - the Sweden Democrats have forged an interpellation that seemingly presents an option for a population in search of an alternative to the visionless politics of the present. This appears, in effect, ironic in the sense that while being basically a one-issue party, its dogma is interpreted as an answer to everything. In this sense, the Sweden Democrats may be seen as a parliamentary manifestation of a contemporary "Polanyian" countermovement. A social movement oscillating in emphasis between antiestablishment and anti-immigrant protest, single-issue racist and extremeright positions (Fennema 1997), but with racism and welfare nostalgia as salient. However, it is becoming an increasingly powerful movement organization through successfully articulating two main positions, merged into a composite counterstrategy for, allegedly, combating the destruction of Sweden. On the one hand, the idea of disembedding the nation from globalization and a supranational EU and, on the other hand, excluding non-deserving "others" from its welfare system or its territory altogether.

The rapidly increasing entry of refugees to Sweden in 2015 has been used actively in the propaganda of the Sweden Democrats. Not only has the party linked refugees to an alleged destruction of Sweden as a nation, but actively attempted to mobilize violent direct action among citizens (Mulinari and Neergaard 2017). While Sweden Democrats staunchly define themselves as neither left nor right, and enjoy a sturdy and increasing electoral support particularly among working class men, in parliamentary politics they are slowly positioning themselves more and more to the right, weaving together racism, authoritarianism and increasingly neoliberalism. In some of the most central left-right conflicts concerning privatization and profits in public finance welfare, labour market legislation, reduced taxation and concerning preferred government, the party has aligned itself with the major rightwing party, Moderaterna (Wingborg 2016). The formal cordon sanitaire around the Sweden Democrats, formerly devised by all other parliamentary parties, has broken down with the announcement of Moderaterna that they 
are prepared to negotiate with Sweden Democrats, together with increasing cooperation on the municipal levels.

On the background of right-wing parties bleeding potential voters to the Sweden Democrats, a Social Democratic and Green Party government in minority, and an unprecedented number of refugees seeking asylum in Sweden, in 2015 the scene was finally set for a dramatic policy shift, toppling an established left-right compact on a comparatively generous refugee policy. Thus, in October 2015 the government struck an agreement with the four right-wing parties concerning refugee and integration policy. Breaking with a principled policy of granting permanent residence following refugee status, temporary residence permits were made the rule, with the explicit purpose of limiting the number of asylum seekers. Possibilities for family unification have been dramatically curtailed. At the same time, future possibilities for permanent residence permits have been linked to labour market integration and family unification and to earning a substantial income through reforms, which in effect directly push refugees into low-wage service work and which breaks with established norms and practices in providing public subvention for job-openings to employers without collective agreements. Asylum policy has, in effect, been adapted to the global apartheid of policies of temporary and circular migration. In November 2015, the Social Democratic and Green Party government announced even harsher refugee and integration policies, preventing refugees from the very opportunity to use the right to apply for asylum. While the neoliberal Centerpartiet voted against this latter reform, there was just one party - the Left party - voting against the reforms of refugee and integration policy as a whole (Neergaard 2017).

Despite scorning the Sweden Democrats as racist and neo-fascist, the Social Democratic and Green government's rupture with decades of Swedish policies for asylum and integration - in the span of less than a year - has made some of the Sweden Democrats' political claims part and parcel of the Swedish migration-policy regime. Furthermore, it has underscored the image of immigration as a threat to Sweden. Nevertheless, the Sweden Democrats continue, in chorus with parts of the old mainstream political right, to propagate further restrictive measures, arguing that deserving "natives" must be treated differently from non-deserving, culturally deviant "foreigners", in order to protect the claims of the former to the scarce resources of a crisis-ridden welfare state in a hardening globalized world (Mulinari and Neergaard 2017; Wingborg 2016).

The party has attracted increasing electoral support through refocusing "cultural" racism towards Muslims and Roma migrants, which increasingly is not only aligning with the established right-wing parties, but increasingly also with the public opinion as expressed in polls (Wingborg 2016). At the same time, there is the continued rhetoric of the traditional core of the party, especially through party linked blogs, web journals and in social 
media, infused with a more blatant and overt racism. Is it possible to understand this development in a Polanyian frame? A historical analogy may help. Like in the case of the alliance of the National Socialists with German big capital in the 1930s - after the purge of the party's militant left wing, the SA Stormtroopers - the position of the Sweden Democrats is ambiguous and opportunistic, reflecting a dual challenge. On the one hand, it is mobilising support as a social movement, in which activists are important. These are activists that are more expressively racist, active especially through social media web blogs and journals (Hellström 2016), but also through manifestations. In this sense, Sweden Democrats may be seen as the central organization in a wider social movement in which racism is the key issue. On the other hand, the leadership is attempting to break the cordon sanitaire with the aim of becoming a potential governmental coalition partner to the right-wing parties. This entails a lower racist profile, targeting "only" Muslims and Roma, but also subscribing to a substantial realignment of economic policy towards a more traditional neoliberal position. This economic realignment with the right has been facilitated through increasing ties with the Confederation of Swedish Enterprise (Svensk Näringsliv) and affiliated organizations. The Swedish publicist, Mathisen (2016), concludes that, "The economic elite in Sweden obviously has interlocking interests with that of parliamentarian fascism." Informal consultations of the confederation with the Sweden Democrats represent, seen in this perspective, the mediating interface of a covert political agreement in becoming. It forges the grounds for an unholy marriage between the exclusionary racism championed by the Sweden Democrats and increasingly permeating most of the right-wing parties, with the exploitative racism of neoliberal capitalism. It guarantees employers long-term access to an abundant cheap and readily disposable global labour force, yet in the same fell swoop, it appeases the extreme right with guarantees that only a chosen minority among these new helots (Cohen 1987) of a globalized apartheid will ever gain access to privileges of citizenship and membership of the nation. However, this repositioning of the Swedish political right is still instable, as exemplified in the increasing support for the neoliberal Centerpartiet, which - while proposing to lower wages for entrants to the labour market, likely to especially target migrants - at the same time refuse to join the bandwagon of the Sweden Democrats' racist discourse.

\section{Reclaiming democracy and citizenship from the ground up}

Another manifestation of today's countermovement comes as urban uprisings. It is, using the term of Chatterjee (2002), a "politics of the governed", in the form of riots of precaritized youth in racialized and socially disadvantaged city regions - in Sweden referred to as "suburbia" (förorten), a term and spatio-social milieu corresponding to the French "banlieus". Extensive 
riots took place in the Swedish cities of Malmö, Gothenburg and Uppsala in 2009, and again in Stockholm, and several other cities, in 2013. We see these so-called riots (Swedish: kravaller) as a rebellion of what has been called an "uncivil society" (Bayat 1997) out of the reach of neoliberal governance. The term signifies a distance to a so-called civil society tamed and disciplined through techniques of governmentality (Neocosmos 2011). In the context, the idiom, "policing the crisis" (Hall et al. 1978) holds as substantial a meaning as ever. A permanent tension between the police and young people, building up across a disadvantaged Swedish suburbia has produced urban hotbeds for rebellion.

In these disadvantaged spaces, mostly populated by migrants and postmigrant generations, the police are the most visible targets for resentment in their function of guarding a regime of financialization, commodification of welfare provision, a grabbing of the commons and extensive gentrification propelling new urban geographies of racialized inequality. These are rambling processes of precarization, which have undermined trust in political institutions and agencies of the state. A widespread frustration among youth of, in particular, migrant background, racialized through systemically embedded stigmatization and discrimination, has, combined with a lack of spaces for democratic participation and decision-making relating to programmes for urban planning (Léon-Rosales and Ålund 2017), generated feelings of powerlessness and became a driving force for their uprising (Schierup, Ålund, and Kings 2014).

The contemporary city constitutes a strategic terrain for conflict and contestation, with "advanced marginality" - a term introduced by Loïc Wacquant (1996) - as point of departure for exploring causes and implications of contemporary urban geographies of poverty and precarization. It highlights processes of institutional transformation, whereby "organizations presumed to provide civic goods and services - physical safety, legal protection, welfare, education, housing and health care - have turned into instruments of surveillance, suspicion and exclusion rather than vehicles of social integration and trust-building". Dikeç (2007) critically deepens the meaning of "advanced marginality", highlighting that deprived neighbourhoods may be actually sprawling with collective grassroots activism. Reflecting on French urban policy, Dikeç emphasizes that space and place cannot be considered as given, but are produced by multiple practices and discourses. Suburban multiethnic districts are, on the one hand, increasingly constituted as "badlands" in public discourse and, on the other hand, exposed to repressive forms of state intervention. But they are also potential or actual sites for political mobilization driven by democratic ideals. Beyond the smokescreen of conspicuous violence, the contemporary Swedish scene also makes visible the emergence of an autonomous, focused and organizationally embedded justice movement contesting urban degradation and reclaiming Sweden in terms of 
inclusive citizenship, social welfare and democracy (Sernhede, Thörn, and Thörn 2016). Out of the boiling cauldron of burning cities, we have thus seen the birth of a new justice movement, with an array of networks, and more or less temporary organizations spearheaded by young people from marginalized urban neighbourhoods with a high proportion of citizens of migrant background, especially from Africa and the Middle East. These are visible minorities stigmatized in terms of "race", "national origin" and "migrant background".

We illustrate in the following how one, among many, local activist organization, The Megaphone (Megafonen), founded and driven by youth, developed counter politics as their answer to police violence, racism, segregation and the lack of democratic participation, in order to bring forward their own voices (cf. Hall 1992a) and claims for deepened democracy onto a wider public-political arena. The Megaphone started in Husby 2008 a neighbourhood in the area of Järvafältet belonging to Metropolitan Stockholm. Activists in the Megaphone present themselves as a Swedish suburban movement (förortsrörelse). The notion of "the suburban movement" was coined in a press release in 26 January 2012 announcing the end of the occupation of Husby träff, a meeting point of local inhabitants. The occupation was a reaction to a series of closures of welfare service institutions, such as schools, health centres, the post office, the municipal office, the social insurance office, etc. (Megafonen 2012).

However, the name of The Megaphone - aiming at becoming the voice of suburbia in response to negative fame inhibiting stigmatizing representation of suburban areas in the mainstream public (Idagsidan 2012) - was disseminated worldwide in connection with the dramatic youth riots in Stockholm in 2013 (Schierup, Ålund, and Kings 2014). Then the Megaphone became known for its sharp critique of the Swedish police and for making public an understanding of the institutional violence, social marginalization, the discrimination and racial stigmatization that led to the Stockholm uprising in the first place. "The Megaphone does not start fires", they stated and continued:

We believe that this is not the right method for long-term change. But we know that it is a reaction to the shortcomings of this society. Unemployment, inadequate schools and structural racism are the underlying causes of what is happening today. ${ }^{5}$ (Megafonen 2013)

Claiming that they represent those whose voices are silenced and excluded from the public arena (Léon-Rosales and Ålund 2017), Al-Khamisi (2015a), one of the founders of The Megaphone, sums up the forward development of the suburban movement as follows: "We understood the need to create our own platforms, structures and activities which allowed us to develop intellectually, socially, mentally as equal citizens." He refers, among other, to the network 
"United Suburbs": a digital platform for organization of "suburban people" making an impact on the Swedish cultural scene. It is one example of becoming a public voice among numerous appearances on conferences, seminars, workshops, festivals and a regular contribution of articles in Swedish mass media.

Still, in its initial formative period, the main impact of the organization, as of the suburban movement in general, has been in organising local communities, the creation of a collective identity related to place (the neighbourhood) and a multifaceted engagement in what is called "place struggle". We see it as a particular contemporary Swedish version of what Sivanandan (1989), with reference to the U.K., calls "organic communities of resistance", presaged in "the black struggles of the 1960s and 1970s", which have also served as ideal models inspiring the young racialized urban Swedes, their organization, their community work, and their national and international networking. The notion of "place struggle" revolves around the shared collectiveidentity work of the inhabitants of marginalized neighbourhoods and comes to be expressed in a composite political agenda addressing problems of segregation, welfare retrenchment and deepening racialized class inequality (León-Rosales and Ålund 2017; Sernhede, Thörn, and Thörn 2016). In what was phrased in terms of a long-term principled political programme, The Megaphone states that they organize suburban youth in a struggle for social justice: "By mobilizing forces that repression breeds in the suburb we want to create a society free of racism, sexism and class oppression", they write on the homepage. ${ }^{6}$ Through a seven-point programme, they demand opportunities for people in the disadvantaged urban neighbourhoods to influence politics which affects the everyday lives of their inhabitants. They demand development and investment in public services and investments to stimulate social activities in the suburbs, a fair educational system and full secondary competence in all schools, work for everyone in the suburbs; the replacement of racialized securitization by sustainable social programmes and a housing policy that recognizes the right to decent housing for all.

\section{"Place struggle", civil society and the state}

We understand the Swedish suburban movement as a "Learning from the Ground up" (Choudry and Kapoor 2010) in which knowledge production and practice/action are interconnected; an interconnection that can bring forward a voice of the subaltern, carrying a critical perspective forward to the wider national context and addressing "tensions over whose knowledge and voice(s) are heard". Related to this, the systematic training of "organic intellectuals" in the art of rhetoric became a key strategy of the urban justice movement to enable participation in public-political discourse. Frustrated by the lack of participation and possibilities to influence local 
renewal programmes they have boosted a more sturdy "public voice" through which the perception of disadvantaged Swedish suburbs and their inhabitants is being anchored in the wider public space (Léon-Rosales and Ålund 2017).

But it is in particular in the new urban justice movement's relation to established Swedish civil-society organizations that we may see an opening towards anti-racist democracy. Discussing experiences of the Swedish urban justice movement with activists from U.S.A., South Africa and France, AlKhamisi, who is a student of law, presented a report (Al-Khamisi 2015b), based on a study visit to the U.S.A., which discusses potentials of social movement lawyering as an instrument in the service of grassroots organizations in promoting social justice. The report, commissioned by Arena Idé, a leading Swedish think tank of the labour movement, illustrates one of several examples of connections between new and old, established, popular movements in Sweden. Another example was a major public event: a conference in Stockholm (6-7 May 2015), organized by a number of civil-society organizations around the issue of "The crisis of Democracy". The aim of the conference reads as follows (Rädda Barnen 2015):

\begin{abstract}
The Swedish social model has grown out of engagement in civil society. Swedish citizens created organizations that have contributed to the development of society, socially, culturally and politically. These popular movements have formed the backbone of Swedish democracy by being the voice of the people in relation to public institutions and private interests. In recent decades, Sweden has undergone major changes. One of the clearest changes is that the composition of the population has changed fundamentally due to migration of people from other parts of the world. The traditional Swedish civil society has in far too small extent managed to incorporate this part of the population in the democratic process. It weakens civil society and the Swedish democracy. This we want to change.
\end{abstract}

The established civil-society organizations (Save the Children, The Workers Educational Association [ABF], People's Parks and Community Centers, Study Promotion, The National Council of Swedish Youth Organisations [LSU]), hosted the conference. The idea was to bring together new movements from suburbia and, as it was announced by hosts, to "create pathways into our organizations for those who are outside, and we want to support the emergence of new organizations that can meet new needs of our society" (Barnen 2015). Obviously, these "new needs" are rooted in the lack of representation of new movements and their voices within the established civilsociety organizations, and beyond.

In this gathering, "voice" was the dominant theme. The focus was on two issues - representation and identity. It underlined that "voice" is pivotal for strategies of representation (Hall 1992a) - in established civil-society organizations, in cultural politics and social practice - as the expression of citizen 
participation through deliberative engagement in local and national political and institutional contexts. The conference on the crisis of democracy enhanced possibilities for collaboration which are already in the process of being realized.

Members of the new urban justice organizations have presently become employed within several established civil-society organizations. We see today an increasing representation of formerly vilified youthful rebels across established and institutionalized civil-society organizations and NGOs, and in influential positions in public services. Many embark on careers within education and the media. This presents us with another challenge in terms of theory and empirical research. What is in the making: co-optation and disciplinary governmentality, or a renaissance for participatory democracy realized through a more mature stage in the short history of the new justice movements?

Potentially this involvement can result in a renaissance of what was once known as "people's movements" being a cradle of Swedish democracy. Today, most of these established movements are rather "tamed", institutionalized and professionalized service organizations making truth of Kaldor's $(2003,589)$ argument that "[b]ecoming 'tamed' means that you become the respectable opposition - the partner in negotiations". But we may alternatively, in a Gramscian perspective, see the current transformation as a more mature face of an innovative anti-racist project transmuted from a strategy for influencing the state from "the outside" towards an "outside-inside" strategy; a war of position, which, through integration with and simultaneous renewal of a multifaceted and contestative Swedish civil society, could increasingly traverse the institutions of the state. And here, returning to Fraser, we can trace the position of emancipatory movements within the wider context of civil society. While interconnecting with parts of established organizations, integrated in state-market "partnerships", urban justice movements have so far, albeit in an ambiguous position, not lost their significance as "parallel discursive arenas where members of subordinated social groups invent and circulate counter discourses to formulate oppositional interpretations of their identities, interests, and needs" (Fraser 1990, 67). They still strive to combine resistance against oppressive norms of racializing stigmatization with claims for inclusionary social protection, as a basis in struggles for emancipation.

\section{Ambiguous fault lines in a precarious present}

Returning to the Polanyian perspective that we have introduced at the beginning of this paper, we argue that the success of neoliberalism has proceeded so far as to almost annihilate all other political projects presenting economic and social alternatives. It pertains in particular to the social democratic project, 
which in its different forms has almost totally succumbed to and internalized the neoliberal agenda. Left parties did or could not muster much of a countermovement to the entrenchment of neoliberalism. It is thus either on the margins that the seeds of a countermovement began to develop, or in the shape of distorted nativist constellations of populist protest, carrying forth fascist and racist movements, and parties.

Similar to other anti-immigration populist movements across Europe, with France's Front National as the exemplary case, a pivotal ideological tenet of the discourse of the extreme-right Sweden Democrats has been a convoluted critique of immigration as political programme and practice. The extremist right has become an increasingly respectable partner for mainstream political parties, for whom social citizenship and universal welfare policies have progressively dried up as sources for legitimacy. The ideologies and discourses of racism are gaining terrain in the EU pertaining, in effect, to a dead end "declassified" (Maré 2014) conception of race; that is with a signification of "race" void of reference to "class" and void of a critique of the political economy on which processes of racialization are contingent (cf. Kyriakides and Torres 2012).

In the second part of our paper, we have discussed the rise of a new urban justice movement among disadvantaged and racially stigmatized youth in terms of an antagonistic opposite to the Sweden Democrats reclaiming Sweden in terms of an inclusive citizenship, social welfare and democracy from the ground up. They present a vision of society that articulates a reimagination of the nation as a future in making; as a multifaceted community of culturally sundry but equal citizens. This brings the matter of race to a head. While the discourse of "the suburb" represents the interpellation of a struggling subject, it is also a contribution to a particular form of applying "race" as a floating signifier? "Place struggle" is at the same time an adumbration alluding to a junction where "race" and "class struggle" coalesce. Reference to the "people of the suburb" is evidently a thin veiling of a call for an open class-conscious pan-racial/ethnic/migrant and post-migrant mobilization of Sweden's racialized. It represents alternative ways of framing a "We" that is constructed through race and class as an anti-racist project. The urban justice movement is a race critical project initiated and chiefly driven by Sweden's most disadvantaged. It mobilizes Swedes of colour and stigmatized descent. But it frames, at the same time, an open project that does not preclude the inclusion of precaritized white folks, under a common umbrella of "We are the Poors"; ${ }^{7}$ a movement from the margin addressing a need for recognition of the excluded as a political voice against the re-emergence of the spectre of totalitarianism in a present turmoil and transformation of democratic frameworks of rights, welfare and nation. 


\section{Notes}

1. Alluding to Hall (1992b).

2. http://www.youtube.com/watch?v=5UiUdpYVubY.

3. http://www.aftonbladet.se/nyheter/article21386442.ab (9 September 2015).

4. http://www.expressen.se/debatt/antisemitismen-lever-inom-sd/ (7 October 2016).

5. Compare, e.g. the analysis by Comité invisible (2007) discussing similar issues in France.

6. http://megafonen.com/om/politiskt-program/.

7. Alluding to Desai's (2002) seminal account of the South African poor people's movement.

\section{Disclosure statement}

No potential conflict of interest was reported by the authors.

\section{Funding}

This work was supported by Forte [2006-1524], Svenska Forskningsrådet Formas [2502013-1547] and Vetenskapsrådet [2007-7269, 721-2013-885].

\section{References}

Al-Khamisi, Rami. 2015a. "Förortsrörelsen existerar mer än någonsin." In ETC. ETC.

Al-Khamisi, Rami. 2015b. Rörelsejurister. Vägen mot en samhällsförändrande juridik - om makt, civilsamhälle och behovet av nya jurister. Stockholm: Arena.

Ålund, Aleksandra, Carl-Ulrik Schierup, and Anders. Neergaard, eds. 2017. Reimagineering the Nation. Essays on Twenty First Century Sweden. Frankfurt am Main: Peter Lang.

Bayat, Asef. 1997. "Un-civil Society: The Politics of the 'Informal People'." Third World Quarterly 18 (1): 53-72.

Block, Fred. 2001. Introduction. The Great Transformation. Boston: Beacon Press.

Chatterjee, Partha. 2002. The Politics of the Governed. New York: Columbia University Press.

Choudry, Aziz, and Dip Kapoor. 2010. Learning from the Ground Up: Global Perspectives on Social Movements and Knowledge Production. New York: Palgrave Macmillan.

Cohen, Robin. 1987. The New Helots: Migrants in the International Division of Labour. Aldershot: Avebury.

Comité invisible. 2007. "L'insurrection qui vient." In La fabrique éditions. Paris: La fabrique.

Desai, Ashwin. 2002. We Are the Poors. Community Struggles in Post-apartheid South Africa. New York: Monthly Review Press.

Dikeç, Mustafa. 2007. Badlands of the Republic. Space, Politics and Urban Policy. Oxford: Blackwell.

Du Bois, W. E. B. 1903. The Souls of Black Folk. Chicago: A.C. Mcurg.

Fennema, Meindert. 1997. "Some Conceptual Issues and Problems in the Comparison of Anti-immigrant Parties in Western Europe." Party Politics 3 (4): 473-492. 
Fennema, Meindert. 2005. "Populist Parties of the Right." In Movements of Exclusion: Radical Right-Wing Populism in the Western World, edited by J. Rydgren, 1-24. New York: Nova Science.

Fraser, Nancy. 1990. "Rethinking the Public Sphere: A Contribution to the Critique of Actually Existing Democracy." Social Text 25 (26): 56-80.

Fraser, Nancy. 2013. "A Triple Movement? Parsing the Politics of Crisis after Polanyi?" New Left Review 81 (May): 119-132.

Hall, Stuart. 1992a. "New Ethnicities." In "Race", Culture and Difference, edited by Donald James and Ali Rattansi, 252-260. London: Sage.

Hall, Stuart. 1992b. "The West and the Rest: Discourse and Power." In Formations of Modernity, edited by Stuart Hall and Bram Gieben. London: Polity Press in Association with The Open University.

Hall, Stuart. 1997. "Race, the Floating Signifier: Transcript of Lecturee Delivered at Goldsmiths College in London." Northampton: MEDIA EDUCATION FOUNDATION. 1-17. http://www.mediaed.org/transcripts/Stuart-Hall-Race-the-Floating-SignifierTranscript.pdf.

Hall, Stuart, Chas Critcher, Tony Jefferson, John N. Clarke, and Brian Roberts. 1978. Policing the Crisis: Mugging, the State and Law and Order. London: Macmillan.

Hellström, Anders. 2016. Trust Us: Reproducing the Nation and the Scandinavian Nationalist Populist Parties. New York: Berghahn Books.

Holmes, Douglas R. 2000. Integral Europe: Fast-Capitalism, Multiculturalism, Neofascism. Princeton, NJ and Oxford: Princeton University Press.

Idagsidan. 2012. "Inte bara snack i Megafonen." In Svenska Dagbladet. Svenska Dagbladet.

Kaldor, Mary. 2003. Global Civil Society. An Answer to War. Cambridge: Polity Press.

Kyriakides, Christopher, and Rodolfo D. Torres. 2012. Race Defaced: Paradigms of Pessimism, Politics of Possibility. Stanford, CA: Stanford University Press.

Laclau, Ernesto. 2005. On Populist Reason. London and New York (NY): Verso.

León-Rosales, René and Aleksandra Ålund. 2017. "Renaissance from the Margins Urban Youth Activism in Sweden." In Reimagineering the Nation. Essays on Swedish Society, edited by B. Author, 353-376. Frankfurt: Peter Lang.

Maré, Gerhand. 2014. Declassified. Moving Beyond the Dead End of Race in South Africa. Auckland Park: Jacana Media.

Mathisen, Daniel. 2016. Svenskt Näringsliv - SD:s maskhål till makten. Stockholm: Dagens Arena.

Megafonen. 2012. "Megafonen kräver respekt." Megafonen. http://megafonen.com/ husby-kraver-respekt/.

Megafonen. 2013. "Uttalande om Megafonens roll under förortsrevolterna." Megafonen. http://megafonen.com/uttalande-om-megafonens-roll-underforortsrevolterna/.

Mudde, Cas. 2010. "The Populist Radical Right: A Pathological Normalcy." West European Politics 33 (6): 1167-1186.

Mulinari, Diana, and Anders Neergaard. 2017. "From Racial to Racist State? The Sweden Democrats Reimagining the Nation." In Reimagineering the Nation. Essays on Twenty First Century Sweden, edited by Aleksandra Ålund, Carl-Ulrik Schierup, and Anders Neergaard, 257-284. Frankfurt am Main: Peter Lang.

Neergaard, A. 2017. "The Swedish Model in Transition: Trade Unions and Racialised Workers." In Reimagineering the Nation. Essays on Twenty First Century Sweden, edited by Aleksandra Ålund, Carl-Ulrik Schierup, and Anders Neergaard, 85-118. Frankfurt am Main: Peter Lang. 
Neocosmos, Michael. 2011. "Transition, Human Rights and Violence: Rethinking a Liberal Political Relationship in the African Neo-colony." Interface: A Journal for and about Social Movements 3 (2): 359-399.

Norocel, Ov Cristian. 2016. "Populist Radical Right Protectors of the Folkhem: Welfare Chauvinism in Sweden." Critical Social Policy 36 (3): 371-390.

Piore, J. Michael. 2008. Presidential Address. Second Thoughts: On Economics, Sociology, Neoliberalism, Polanyi's Double Movement and Intellectual Vacuums. SASE Meeting 2008. Economic Flexibility and Social Stability in the Age of Globalization. SASE: San Juan, Costa Rica.

Polanyi, Karl. (1944) 2001. The Great Transformation: The Political and Economic Origins of Our Time. Boston, MA: Beacon Press.

Pred, Allan. 2000. Even in Sweden. Racisms, Racialized Spaces, and the Popular Geographical Imagination. Los Angeles: University of California.

Rädda Barnen. 2015. "Demokratins kris är vår - vad gör vi åt den?" Save the Children. Accessed January 25, 2016. http://www.mynewsdesk.com/se/radda_barnen/ documents/demokratins-kris-aer-vaar-vad-goer-vi-aat-den-45358.

Rydgren, Jens. 2002. "Radical Right Populism in Sweden: Still a Failure, But for How Long?" Scandinavian Political Studies 25: 27-56.

Schierup, Carl-Ulrik, and Aleksandra Ålund. 2011. "The End of Swedish Exceptionalism? Citizenship, Neoliberalism and the Politics of Exclusion." Race \& Class 53 (1): 45-64.

Schierup, Carl-Ulrik, Aleksandra Ålund, and Lisa Kings. 2014. "Reading the Stockholm Riots - a Moment for Social Justice?" Race \& Class 55 (3): 1-21.

Schierup, Carl-Ulrik, and Simone Scarpa. 2017. "How the Swedish Model Was (Almost) Lost. Migration, Welfare and the Politics of Solidarity." In Reimagineering the Nation. Essays on Twenty First Century Sweden, edited by Aleksandra Ålund, Carl-Ulrik Schierup, and Anders Neergaard. Frankfurt am Main: Peter Lang.

Sernhede, Ove, Catharina Thörn, and Håkan Thörn. 2016. "The Stockholm Uprising in Context: Urban Social Movements and the Rise and Demise of the Swedish Welfare State City." In Urban Uprisings: Challenging Neoliberal Urbanism in Europe, edited by M. Mayer, C. Thörn, and H. Thörn, 353-376. Basingstoke: Palgrave Macmillan.

Sivanandan, Ambalavaner. 1989. "All That Melts into Air Is Solid: The Hokum of New Times." Race \& Class 31 (3): 1-30.

Wacquant, Loïc. 1996. "The Rise of Advanced Marginality: Notes on its Nature and Implications". Acta Sociologica 39 (2): 121-139.

Wingborg, Mats. 2016. Den blåbruna röran: SD:s flirt med Alliansen och högerns vägval. Stockholm: Leopard. 